\title{
SUBAK BERBASIS TRI HITA KARANA DALAM MELESTARIKAN DAN MEMPERTAHANKAN PARIWISATA BUDAYA DI ERA MODERN DI KABUPATEN GIANYAR
}

\author{
Oleh : \\ I Wayan Eka Artajaya SH.,M.Hum \\ Program Studi, Fakultas Hukum Universitas Mahasaraswati Denpasar \\ Jl. Kamboja, No. 11A, Dangin Puri Kangin, denpasar Utara, Bali 80233 \\ (iwayanekaartajaya@gmail.com)
}

\begin{abstract}
Abstrak
Bali sebagai tempat pawisata memang mempunyai daya tarik tersendiri dibandingkan dengan tempat wisata lainnya, daya tarik pulau bali yang kuat adalah di bidang pariwisata mulai dari kindahan alam, keindahan pantai, beragam seni dan budaya. Salah satu keunikan yang bisa menarik wisatawan untuk datang ke pulau bali adalah pariwisata di bidang terasering atau yang dikenal dengan sistem irigasi subak. Seiring perkembangan jaman yang semakin modern, sistem irigasi tradisional sudah mulai di tinggalkan oleh sekaha penggarap dan beralih menggunakan alat yang semakin canggih. Subak berbasis Tri Hita Karana dalam Melestarikan dan Mempertahan Pariwisata Budaya di Era Modern di Kabupaten Gianyar. Pembahasan Tri Hita Karana dengan desa pakraman merupakan benteng terakhir untuk menjaga kelestarian, keamanan serta mempertahankan budaya bali Khususnya sistem irigasi subak di Kabupaten Gianyar yang sudah menjadi warisan dunia. Pelestarian Subak dilakukan dengan pembentukan awig-awig larangan penggunaan mesin dan bahan zat kimia dalam sistem irigasi subak dan awig-awig terkait alih fungsi lahan pertanian, sehingga tercapainya pariwisata subak yang berbasis Tri Hita Karana.
\end{abstract}

\section{Kata kunci; Subak, Tri Hita Karana, dan Pariwisata Budaya}

\section{Abstract}

Bali as a place of tourism it has its own attraction than with the other touris, the appeal of the island of Bali which is in the field of tourism from the beauty of nature, the beauty of the beaches, diverse arts and culture. One of the uniqueness that can attract tourists to come to the island of bali is tourism in the field of terasering the ones in familiar wits this traditional subak. Along with the development of a more modern, irrigation system traditionally, has been on leave by Sekaha tiller and switched to using the increasingly sophisticated. Subak based on Tri Hita Karana in preserving and maintaining of tourism cultur in the era of modern in Gianyar. Discussion Tri Hita Karana with his village Pakraman is the last fortress 
to preserve the security and protecting the culture of bali, especially on iririgation system subak in Gianyar that has become a world heritage. The subak be done with the establishment of a awig-awig the ban on the use of machines and chemicals in an irrigation system subak and awig-awig associated over the functions of agricultural land, so that the achievement of the subak based on Tri Hita Karana.

Keywords : Subak, Tri Hita Karana and Tourism Culture.

\section{A. Latar Belakang Masalah}

Negara Indonesia merupakan Negara kepulauan dan lautan yang jumlah penduduknya sangat padat, sebagain besar penduduk Indonesia bermata pencaharian sebagai petani. Tingkat ketergantungan akan ketersediaan tanah bagi para petani sangat tinggi. Persedian terhadap lahan pertanahan sebagai tempat tinggal dan lahan pertanian sangat terbatas seiring dengan perkembangan jaman. Tanah sebagai karunia Tuhan Yang Maha Esa merupakan sumber daya alam yang sangat diperlukan manusia untuk mencukupi kebutuhan, baik yang

1 Suardi 2005. Hukum Agraria.

Badan Penerbit IBLAM Jakarta,hI

1. langsung untuk kehidupannya seperti untuk bercocok tanam atau tempat tinggal, maupun untuk melaksanakan usaha, seperti untuk tempat perdagangann, industri pertanian, perkebunan, pendidikan, pembangunan sarana dan prasarana lainya ${ }^{1}$.

Tanah merupakan sesuatu yang memiliki nilai yang sangat penting di dalam kehidupan masyarakat. Hal ini disebabkan karena tanah memiliki nilai ekonomis, sekaligus magisrelegio kosmis. Menurut pandangan bangsa Indonesia, tanah sering memberi getaran di dalam kedamaian 
dan sering pula menimbulkan goncangan dalam masyarakat, lalu ia pula yang sering menimbulkan sendatan dalam pelaksanaan pembangunan Nasional ${ }^{2}$. Dilihat dari sisi lain tingkat pertumbuhan penduduk tidak dapat dibendung yang menyebabkan meningkatnya kebutuhan akan tanah semakin meningkat.

Perkembangan pariwisata di bali telah tumbuh dari masa penjajahan belanda. Bali sebagai tempat pawisata memang mempunyai daya tarik tersendiri dibandingkan dengan tempat wisata lainnya, daya tarik pulau bali yang kuat adalah di bidang pariwisata mulai dari kindahan alam, keindahan pantai, beragam seni dan budaya, dan bali juga di kenal sebagai pulau pura seribu pura. Salah satu keunikan yang bisa menarik wisatawan untuk datang ke pulau bali adalah pariwisata di bidang terasering atau yang dikenal

2 John Salindeho 1998, Masalah

Tanah Dalam Pembangunan, Sinar Grafika, Jakarta, hl 7. dengan sistem irigasi subak. Terasering adalah susunan persawahan yang bertingkat-tingkat yang memiliki keindahan dan daya tarik tersendiri bagi wisatwan. Wisata terasering yang sangat terkenal di bali adalah adalah terletak di Babupaten Gianyar yaitu tepatnya di Desa Tegallalang, tegallalang merupakan obyek pariwisata yang terkenal dengan panorama keindahan alamnya khususnya hamparan persawahan.

Keindahan pariwisata yang terdapat dikedua tempat tersebut tidak terlepas dari sistem irigasi tradisional "Subak" yang dilakukan oleh para Sekaha Subak dalam mengelola lahan pertaniannya yang berbasis Tri Hita Karana. Seiring perkembangan jaman dan pertubuhan penduduk permasalahan terhadap sistem irigasi mulai bermunculan, mulai dari banyak terjadinya alih fungsi lahan, dan jarangnya orang mau untuk menjadi 
petani. Alih fungsi lahan tidak dapat dihindari, hal ini terjadi karena membludaknya wisatawan yang datang ke bali dan kurangnya infrastruktur untuk penunjang pariwisata. Lahan pertanian yang ada di bali sudah mulai terkikis dengan banyaknya lahan pertanian beralih fungsi menjadi restaurant, villa, maupun pemukiman masyarakat karena di nilai menguntungkan dari pada mengolah lahan pertanian.

Seiring perkembangan jaman yang semakin modern, sistem irigasi tradisional sudah mulai di tinggalkan oleh sekaha penggarap dan beralih menggunakan alat yang semakin canggih. Hal ini dilihat pada saat pembajakan sawah yang dulunya masih menggunakan pembajakan tradisional dengan menggunakan sapi, sudah berubah menggunakan mesin, penggunaan pupuk yang berlebihan dan bahan pestisida yang bisa menyebabkan rusaknya kualitas dari hasil panen serta penggarapan sawah yang dulu dilakuan secara tradisiolan dengan sekaha subak sudah mulai di tinggal, hilangnya dilai gotong royong dari masing-masing sekaha subak.
Perkembangan jaman yang semakin canggih menyebabkan berkurangnya minat seseorang untuk menjadi petani, hal ini berdampak pada alih fungsi lahan yang nantinya akan menyebabkan lahan pertanian semakin berkurang dan pengerjaan sawah justru penggunakan alat-alat modern dimana hal tersebut sangat bertentangan dengan konsep dasar Tri Hita Karana. Hal ini bisa berdampak pada hilangnya sistem irigasi subak dan berkurangnya kunjungan pariwisata yang datang ke bali khususnya ke Tegallalang.

Pariwisata di bali sangat tergantung dengan keberadaan kebudayaan, sekaha maupun lembagalembaga adatnya.

\section{B. Rumusan Masalah}

Subak berbasis Tri Hita Karana dalam Melestarikan dan Mempertahan Pariwisata Budaya di Era Modern di Kabupaten Gianyar

\section{Pembahasan}

Subak berbasis Tri Hita Karana dalam Melestarikan dan Mempertahan Pariwisata budaya di Era Modern di Kabupaten Gianyar 
Fungsi utama dari sistem irigasi subak adalah pengelolaan air untuk bercocok tanam padi, khususnya beras, yang merupakan makanan pokok utama bagi orang Bali. Keunikan subak yang ada di Kabupaten Gianyar Khususnya di Tegallalang adalah pelaksanaan kegiatan ritual keagamaan yang di dekenal dengan istilah Mekukung. Mekukung adalah upacara keagamaan yang dilakukan oleh keanggotaan sekaha subak sebelum memulai untuk bercocok tanam, hal inilah yang membedakannya dengan sistem isigasi yang ada di Indonesia dan menjadi daya tarik tersendiri bagi wisatawan untuk berlibur ke bali. Sejak 29 Juni tahun 2012 Subak sebagai Warisan Budaya Dunia yang di tetapkan oleh UNESCO, hal ini merupakan anugrah yang di dapat oleh masyarakat bali Khususnya keanggotaan subak untuk bisa mempertahankan dan menjaga dari perkembangan jaman hal-hal alih fungsi lahan pertanian.

Perkembangan jaman yang semakin modern serta pertubuhan pariwisata yang semakin meningkat tidak selalu membawa nilai yang positif bagi perkebangan pariwisata Bali. Dampak negatif yang mungkin tidak tergambar oleh masyarakat adalah kelestarian subak yang sudah mulai terancam untuk ditinggalkan, hal ini bisa dilihat dari berkurangnya lahan pertaniian yang berubah menjadi hunian atau beralih fungsi. Maka sangat diperlukan adanya kebijakan pemerintah yang kondusif dan perhatian oleh desa pakraman untuk menjaga kelestarian subak. Mundurnya kebudayaan Bali sangat tergantung pada lembaga tradisional, sedangkan pariwisata tergantung pada kebudayaan, maka secara hipotetik dapat dikatakan bahwa eksistensi pariwisata Bali tergantung pada eksistensi dari kebudayaan khsusnya kebudayaan subak.

Menurut pengertian masyarakat adat Bali, Subak merupakan sistem irigasi yang dijalankan secara tradisional dan telah menjadi kegiatan secara turuntemurun untuk mengolah lahan pertanian yang ada di setiap desa pakraman. Definisi lain tentang Subak terdapat pada Perda Provinsi Bali No.9 Tahun 2012 tentang Subak dinyatakan 
bahwa Subak adalah organisasi tradisional di bidang tata guna air dan atau tata tanaman di tingkat usaha tani pada masyarakat adat di Bali yang bersifat sosioagraris, religius, ekonomis, yang secara historis terus tumbuh dan berkembang. Pelestarian subak perlu dilakukan untuk mempertahan budaya adat bali yang berlandaskan Tri Hita Karana.

Kestrukturan organisasi Subak hampir sama dengan struktur organisasi masyaakat adat pada umumnya yaitu terdapat ketua, wakil ketua, sekretaris dan bendahara. Pada organisasi Subak keangotan pengurusnya dipimpin oleh pekaseh (pimpinan Subak) yang dibantu oleh beberapa orang petajuh (wakil). Penyarikan (sekretaris) dan juru raksa (bendahara) Apabila Subak memiliki wilayah yang luas dan jumlah anggotanya ratusan maka akan dibagi lagi dalam bentuk tempekan yang dipimpin oleh kelian tempekan. Untuk mengatur anggotaanggotanya, Subak memiliki aturan

\footnotetext{
${ }^{3}$ Wayan P. Windia dan Ketut Sudantra, 2006, Pengantar Hukum Adat Bali, Lembaga
}

tersendiri yang disebut awig-awig Subak. Awig-awig Subak dibuat berdasarkan hasil dari musyawarah para anggota Subak atau lebih dikenal dengan sangkepan. Aturan Subak berisi perintah, larangan dan kebolehan serta sanksi dalam kelembagaan Subak. ${ }^{3}$

Dalam pasal 3 Peraturan Daerah Provinsi Bali Nomor 9 Tahun 2012 tentang Subak, tujuan Subak mencangkup a. memelihara dan melestarikan organisasi Subak; b. mensejahterakan kehidupan petani; c. mengatur pengairan dan tata tanaman; d. melindungi dan mengayomi petani; dan e. memelihara serta memperbaiki saluran air ke sawah. Dan menurut pasal 8 Peraturan Daerah Provinsi Bali Nomor 9 Tahun 2012 tentang Subak yaitu Subak sebagai organisasi tradisional mempunyai fungsi, antara lain:

a. Membantu pemerintah dalam meningkatkan pembangunan dibidang pertanian; 
b. Melaksanakan hukum adat dan adat istiadat dalam Subak;

c. Menetapkan awig-awig sebagai suatu kesepakatan dalam mengatur kepentingan sosial pertanian dan keagamaan;

d. Membina dan melestarikan nilai-nilai agama dan adat istiadat Bali serta tetap menjaga persatuan dan kesatuan anggota berdasarkan filosofi Bali sagilik saguluk salunglung sabayantaka, paras poros saparnaya, saling asah, saling asih, saling asuh (bersatu-padu menyusun kekuatan menghadapi ancaman/bahaya, memutuskan sesuatu secara musyawarah mufakat, saling mengingatkan, saling menyayangi, dan saling membantu);

e. Menjaga, memelihara, mengembangkan dan memanfaatkan kekayaan Subak dan prasaranaprasarana irigasi lainnya guna menjamin kelancaran tertibnya irigasi dalam mewujudkan kesejahteraan masyarakat;

f. Mengembangkan kemampuan krama Subak untuk meningkatkan produktifitas, pendapatan dan kesejahteraan petani; dan

g. Menjaga kelestarian wilayah Subak dan lingkungannya dalam rangka pertanian berkelanjutan.

Strategi pelestarian subak agar tidak tergeser oleh perkembangan jaman dan teknologi diera jaman sekarang adalah dengan sistem subak berbasis Tri Hita Karana, Tri Hita Karana merupakan suatu sistem yang paling baik dilakukan untuk menjaga kelestarian sistem irigasi subak dan pariwisata budaya pulau Bali jaman saat ini. Dalam menjalankan kehidupan bermasyarakat dan berorganisasi, masyarakat adat Bali mempunyai konsep Tri Hita Karana sebagai landasannya. Menurut pengertiannya Tri Hita Karana adalah tiga penyebab kesejahteraan di dalam kehidupan manusia. Pengertian tersebut diambil dari masing-masing katanya 
yaitu Tri yang artinya tiga, Hita yang artinya sejahtera dan Karana yang artinya penyebab. ${ }^{4}$ Konsep Tri Hita Karana memiliki 3 (tiga) unsur:

\section{a. Parhyangan}

mencerminkan hubungan yang harmonis antara manusia dengan tuhan (Sang Hyang Widhi Wasa) manusia diharapkan memiliki kedekatan batin dengan dengan tuhan, dan setiap dari aktivitasnya didasari oleh semangat, hati yang tulus dan iklas.

b. Pawongan mencerminkan hubungan yang harmonis antara manusia dengan manusia sebagai sesama ciptaan tuhan, dan memiliki hak dan kewajiban yang sama. Dalam hubungan manusia dengan manusia ini diharapkan muncul sebuah ikatan persaudaraan antar sesama manusia. c. Palemahan mencerminkan hubungan yang harmonis antara manusia dengan alam semesta, manusia diharapkan memiliki tanggung jawab menjaga alam dan melestarikan alam agar tercapainya kesemimbangan.

Dari penjelasan tentang Tri Hita Karana di atas, Tri Hita Karana merupakan sebuah dasar filosofi orang hindu dalam menjalankan kehidupannya. Penerapan Tri Hita Karana dalam sistem irigasi subak dewasa ini sangat penting dilakukan, sebeb sistem ini salah satu sistem yang dapat mempertahankan budaya subak agar tetap eksis dan menjadi pariwisata budaya.

a. Parhyangan

mencerminkan hubungan yang harmonis antara manusia dengan Tuhan (Sang Hyang Widhi Wasa) manusia diharapkan memiliki kedekatan batin

${ }^{4}$ Wayan P. Windia, 2004, DandaPacamil, Upada Sastra, Denpasar, h. 131 
dengan tuhan, dan setiap

dari aktivitasnya didasari

oleh semangat, hati yang tulus dan iklas. Sistem irigasi subak memiliki sistem yang bersifat magis relegius, banyak kegiatan keagamaan yang dilakukan oleh sekaha subak sebelum menanam padi hingga menjadi beras. Seperti halnya tradisi Mekukung, mekukung di kenal di masayrakat subak Gianyar sebagai upacara syukuran terhadap padi yang sudah mulai berbuah. Mekukung dilakukan oleh sekaha subak terhadap bidang sawah yang menjadi garapannya, upacara mekukung merupakan upacara yang sangat unik karena upacara tersebut dilakukan sebulum matahari terbit tepatnya di sawah yang menjadi garapannya. Setelah penan masyarakat melakukan upacara setiap sukra umanis kelau atau hari baik menurut kepercayaan masyarakat gianyar. Upacara ini dilakukan di krumpu (lumbung) tempat penyimpenan gabah atau hasil panen. Seseorang yang memiliki lahan persawahan yang ikut dalam keanggotaan subak memiliki lumbung yang terletak di pekarangan rumahnya. Hal ini dilakukan untuk mengucap syukur kepada Tuhan (Sang Hyang Widhi Wasa) terhadap hasil panen yang diperoleh. Setelah upacara tersebut dilakukan baru hasil panen tersebut bisa diolah menjadi beras.

b. Pawongan mencerminkan hubungan yang harmonis antara manusia dengan manusia sebagai sesama ciptaan tuhan, dan memiliki hak dan kewajiban yang sama. Dalam hubungan manusia dengan manusia ini 
diharapkan muncul sebuah

ikatan persaudaraan antar

sesama manusia.

Hubungan yang harmonis

antara manusia dengan

manusia dilakukan pada

saat penanam padi dan

memanen hasil padi,

biasanya ini merupakan hal

yang ditunggu oleh

wisatwan kitika melakukan

pemanenan hasil padi

sekaha subak bergiliran

membantu untuk memanen

padi secara gotong royong.

Dari ghal tersbut sangat

Nampak sekali hubungan

antara manusia lyang satu

dengan manusia yang

lainnya memiliki hubungan

yang harmonis.

c. Palemahan mencerminkan hubungan yang harmonis antara manusia dengan alam semesta, manusia diharapkan memiliki tanggung jawab menjaga alam dan melestarikan alam agar tercapainya kesemimbangan.
Pelemahan merupakan hal yang paling penting dilakukan oleh sekaha subak dalam mempertahannya alam semesta, pariwisata budaya dan sistem subak. Pelaksanaan pembajakan sawah yang berdasar Tri Hita Karana adalah dengan tidak menggunakan mesin pembajak melainkan menggunakan sapi dalam penggarapannya. Tidak mempergunakan pupuk yang mengandung zat kimia yang dapat menyebabkan rusaknya alam hasil panen, dan ekosistem yang hidup di sawah. Hal ini sangat berpengaruh besar terhadap perkembangan pariwisata bali ketika semua penggunakan alat pembajakan sawah yang menggunakan alat tradisional dan tampa zat kimia dapat memberikan daya tarik tersendiri bagi 


\begin{abstract}
wisatawan terhadap
keunikan dari sistem irigasi

subak yang berbais Tri Hita

Karana. Selain menarik wisatawan sistem subak yang berbasis Tri Hita Karana ini kedepannya dapat mencegah kerusakan lingkuangan dan menjaga budaya dan melestarikan sistem irigasi subak dari perkembangan jaman.
\end{abstract}

Tri Hita Karana dengan desa pakraman merupakan benteng terakhir untuk menjaga kelestarian, keamanan serta mempertahankan budaya bali Khususnya sistem irigasi subak yang sudah menjadi warisan dunia. Selain desa pakraman yang menjadi benteng lainnya adalah keberadaan keanggotaan sekaha subak harus tetap terlindungi eksistensinya baik dari desa pakraman maupun dari pemeritahan daerah terhadap alih fungsi lahan yang begitu cepat. Pencegahan tersebut bisa dilakukan dengan membikin awig-awig larangan

\footnotetext{
${ }^{5}$ Drs. I Wayan Astika, 2015 “Eksistensi subak dalam MenghadapiTtantangan Global di Era Modernisasi"
}

penggunakan mesin dan bahan zat kimia dalam sistem irigasi subak dan awig-awig terkait alih fungsi lahan pertanian di Kabupaten Gianyar.

Sistem irigasi subak yang berbasis Tri Hita Karana bisa menjadi sector pariwisata berbais budaya (agriculture-based tourism) atau agro tourism. Hal ini bisa menjadi salah satu tonggak untuk mempertahankan subak sebagai warisan dunia agar tidak punah dimakan jaman. Pelestarian subak tidak bisa dilakukan dengan terpisah, melainkan harus diimbangi dengan pelesatirian lahan pertanian agar kelestarian budaya subak tetap terjaga, serta Subak sebagai organisasi petani dituntut untuk mampu menciptakan kondisi yang dapat menarik kaum muda untuk bekerja sebagai petani modern dan profesional ${ }^{5}$. Pelestarian subak dan lahan pertanian harus di tindaklanjuti dengan pembentukan awig-awig terhadap pelestarisan pariwisata subak yang berbasis Tri 
Hita Karana dan awig-awig terhadap alih fungsi lahan pertanian.

\section{Kesimpulan dan Saran}

\section{A. Kesimpulan}

Strategi pelestarian subak di Kabupaten Gianyar agar tidak tergeser oleh perkembangan jaman dan teknologi diera jaman sekarang adalah dengan sistem subak berbasis Tri Hita Karana, Tri Hita Karana merupakan suatu sistem yang paling baik dilakukan untuk menjaga kelestarian sistem irigasi subak dan pariwisata budaya di Kabupaten Gianyar saat ini. Tri Hita Karana memiliki pengertian dalam kehidupan masyarakat Bali yang selelu menghendaki adanya perimbangan antara kehidupan lahir dan batin dengan tetap berpegang teguh pada ajaran Agama Hindu

Tri Hita Karana dengan desa pakraman merupakan benteng terakhir untuk menjaga kelestarian, keamanan serta mempertahankan budaya bali Khususnya sistem irigasi subak di Kabupaten Gianyar yang sudah menjadi warisan dunia. Selain desa pakraman yang menjadi benteng lainnya adalah keberadaan keanggotaan sekaha subak yang ada di Kabupaten Gianyar harus tetap terlindungi eksistensinya baik dari desa pakraman maupun dari pemeritahan daerah terhadap alih fungsi lahan yang begitu cepat. Pencegahan tersebut bisa dilakukan dengan pembentukan awigawig larangan penggunakan mesin dan bahan zat kimia dalam sistem irigasi subak dan awig-awig terkait alih fungsi lahan pertanian.

\section{B. Saran}

Diharapkan bagi masyarakat agar bersemangat dan menyadari kembali tentang arti pentingnya nilainilai kearifan lokal bagi pengelolaan lingkungan secara berkelanjutan guna mendukung kesejahteraan masyarakat. Setelah didirikannya Organisasi Subak di Kabupaten Gianyar dapat menunjang sistem irigasi dan menunjang pariwisata di pulau bali. Pelestarian subak yang berbasis Tri Hita Hita Karana, harus di tindaklanjuti dengan pembentukan awig-awig terhadap pelestarisan pariwisata subak yang berbasis Tri Hita Karana. Perlu adanya peren dari desa pakraman untuk mempertahankan subak dengan 
pembikinan awig-awig terhadap alih fungsi lahan pertanian, awig-awig larangan penggunaan mesin dalam kegiatan subak, dan larangan penggunaan bahan berbahan zat kimia untuk tercapainya sistem subak yang berbasis Tri Hita Karana.

\section{DAFTAR PUSTAKA}

\section{BUKU ;}

Suardi 2005. Hukum Agraria. Badan Penerbit IBLAM Jakarta

John Salindeho 1998, Masalah Tanah Dalam Pembangunan, Sinar Grafika, Jakarta
Wayan P. Windia, 2004, DandaPacamil, Upada Sastra, Denpasar.

Wayan P. Windia dan Ketut Sudantra, 2006, Pengantar Hukum Adat Bali, Lembaga Dokumentasi dan Publikasi Fakultas Hukum Universitas Udayana, Denpasar, hlm 69

Drs. I Wayan Astika, 2015 "Eksistensi subak dalam MenghadapiTtantangan Global di Era Modernisasi

\section{UNDANG-UNDANG}

Perda Provinsi Bali No.9 Tahun 2012 tentang Subak 